\title{
Emerging intervention of antidepressant with DMARD in non-cancerous nociceptive persistent pain associated depression in FCA induced rheumatoid arthritic rats
}

\author{
Sudhakar Pachiappan ${ }^{\circledR 1^{*}}$, Sudaroli Murugaiyan², Sabarinath Chandrasekar ${ }^{1}$ \\ ${ }^{1 *}$ Department of Pharmacology and Toxicology, Swamy Vivekanandha College of \\ Pharmacy, Tiruchengode, Tamil Nadu- 637 205, India, ${ }^{2}$ Department of Pharmacology, \\ C.L. Baid Metha College of Pharmacy, Chennai, Tamil Nadu, India
}

\begin{abstract}
Rheumatoid arthritis (RA) is a chronic inflammatory disorder that causes pain, systemic complications and premature mortality. Depression has also been identified as a problem for persons with RA. This association remaining significant even after the degree of disease activity is controlled. In the present study, the efficacy of combination therapeutic effect of antidepressant (amitriptyline) with Disease Modifying Anti rheumatoid drug (leflunomide) was determined in rheumatoid arthritis pain associated depression in Freund's complete adjuvant (FCA) induced arthritic rats. Drug treatment was started 9 days after induction of FCA induced arthritis in rats. The antiarthritic activity was assessed by measuring paw volume, weight-bearing, hematological, biochemical, serological parameters, Radiographic analysis and Histopathology of tibiotarsal joints. The antidepressant activity was assessed by Forced swimming test, Rota-rod test and confirmed by estimation of brain neuro transmitters (serotonin and norepinephrine) level. Results of this study revealed that leflunomide and amitriptyline combination showed more significant $(\mathrm{p}<0.001)$ antiarthritic and antidepressant action and leflunomide alone treatment showed significant $(p<0.001)$ antiarthritic activity only as compared to arthritic control. The leflunomide and low dose amitriptyline combination found to be more effective in pain associated depression in rheumatoid arthritic rats.
\end{abstract}

Keywords: Arthritis associated depression. Freund's complete adjuvant. Amitriptyline. Leflunomide.

\section{INTRODUCTION}

Rheumatoid arthritis (RA) is a systemic inflammatory chronic progressive and prototypical autoimmune disease. It may affect many tissues and organs but primarily attacks the synovial joints. Pain is one of the most important symptoms reported by RA patients (Merskey, 1979). This pain results from the arthritic tissue inflammation, the release of inflammatory mediatory mediators such as

*Correspondence: S. Pachiappan. Department of Pharmacology, Swamy Vivekanandha College of Pharmacy, Tamil Nadu, India, Namakkal-637 205. Mobile: +919600616196. E-mail: sudhakar00pharma@gmail.com interleukins (IL), prostaglandins (PGs), nitrous oxide (NO), Tumor necrosis factor (TNF), bradykinin and excessive tension on the joints. An ever- increasing body of research confirms that rheumatoid arthritis is also associated with depression (Creed, 1990; Frank et al., 1988). Depressive disorders occur in $20-25 \%$ of patients with RA.

Depression in RA patients is associated with an increased level of pain. However the causal relationship between pain and depression may act in both directions with pain increasing depression and depression increasing pain (Magni et al., 1994). Depression is also associated with increased functional disability and burden in rheumatoid arthritis patients. This 
association has been shown to be remaining significant even after the degree of disease activity is controlled (Challahan et al., 1991). This type of depression is accompanied by activation of immune, inflammatory, oxidative and nitrosative stress (IO\&NS) pathways, also accompanied by activation of structural changes in the hippocampus, prefrontal cortex, amygdala, anterior cingulate and basal ganglia (Maes et al., 1995). It also causes by increased production of proinflammatory cytokines such as IL-1 $\beta$, IL-6 and tumor necrosis factor- $\alpha$ (TNF- $\alpha$ ); and acute phase response (Campbell, Macqueen, 2006).

In such causes the current therapeutic approaches of specific disease-modifying anti-rheumatoid drugs (DMARDs) and standard analgesics (NSAIDs and opioids) alone are ineffective. Many of the patients and practitioners are seeking alternative approaches to provide an effective cure in the treatment of RA condition (Perrot et al., 2009). Hence this study made an attempt for an alternative therapeutic approach by using an antidepressant which posse significant analgesic and anti-inflammatory action along with standard antiarthritic agents.

Among the current anti-arthritic agents DMARDs is the drug which decreases the arthritic condition by altering the cause and acts on the disease progression of RA. In this class the selected leflunomide posse potent anti-arthritic action by inhibiting both the T-cell and B-cells with a subsequent inhibition of antibody (RF) production. Previous studies reported that some of the anti-depressants have been shown to have significant anti-inflammatory and anti-nociceptive effects in several rheumatological conditions and could be tested in patients with chronic pain related to rheumatic disorders (Yaron et al., 1999; Fishbain, 2000; Sullivan, Robinson 2006; Curatolo, Bogduk 2001). In antidepressant classes tricyclic antidepressants (TCAs) have been recommended for many years to treat chronic pain from various causes. Here we selected amitriptyline, is a tricyclic antidepressant non-selectively inhibits the reuptake of NE and 5-HT; also using in ankylosis spondylitis for pain relief and in some European countries it is officially approved for patients with frequent/ chronic migraines (25-75 $\mathrm{mg}$ ). Besides, the present study is intense to explore the combined therapeutic effect of antidepressant (amitriptyline) with potent and efficacies DMARD (leflunomide) on pain associated depression in FCA induced RA rats.

\section{MATERIAL AND METHODS}

\section{Material}

All the chemicals used in this study were of analytical grade. Attenuated Mycobacterium tuberculosis organism obtained from Indian Council of Medical Research (ICMR), Chennai. leflunomide marketed sample purchased from Cadila health care Ltd, Ahmedabad, amitriptyline purchased from Vashudha Pharma Chem Ltd., Chennai, and Biochemical diagnostic kit were from Merck Specialties Pvt. Mumbai.

\section{Animals}

The colony inbred mature male Albino Wistar rats, weighing between 150-200 gms were obtained from the animal house in C.L. Baid Metha College of Pharmacy, Chennai. The animals were kept under standard environmental conditions of 12/12 light/dark rhythm, maintained under controlled $\left(23 \pm 2{ }^{\circ} \mathrm{C}\right)$ room temperature, in polypropylene cages. They were fed with standard pellet diet and water ad libitum. The immature animals were acclimatized under laboratory conditions three days prior to the initiation of the experiment. The cages were cleaned daily by changing the sawdust bedding. The animal care and experimental protocols were in accordance with the Institutional Animal Ethical Committee (IAEC) (Approval no: IAEC/XXX/09/ CLBMCP/2010 DATED: 22-09-2010).

\section{Induction of FCA induced arthritis}

Rats were randomly divided into five groups of six animals each where, Group I - Vehicle control receives $0.5 \mathrm{~mL}$ of normal saline, p.o. Group II - Arthritic control (100 $\mu \mathrm{l}$ of $F C A$ in to sub plantar region) receives $0.5 \mathrm{~mL}$ of normal saline, p.o. Group III - FCA + leflunomide (12 mg/kg/day, p.o). Group IV - FCA + leflunomide (12 $\mathrm{mg} / \mathrm{kg} /$ day, p.o) + amitriptyline $(9 \mathrm{mg} / \mathrm{kg} /$ day, p.o) Group V - FCA + leflunomide (12 mg/ kg/day, p.o) + amitriptyline ( $18 \mathrm{mg} / \mathrm{kg} /$ day, p.o.).

Adjuvant arthritis was induced by subcutaneous injection of FCA $(100 \mu \mathrm{l}$ of $5 \mathrm{mg} / \mathrm{mL}$ suspension of Heat killed Mycobacterium tuberculosis organism in liquid paraffin) in to sub planter tissue of the right hind paw of each rat except vehicle treatment group using 26 gauge needle. Paw volume was measured after six-hour of FCA 
injections was considered as day one measurement and it was continued till $21^{\text {st }}$ day. The drug treatment was started on day 9 after induction of arthritis and continued till $21^{\text {st }}$ day of study, drugs are dosed once daily through orally (Sudaroli, Chatterjee 2007; Kumar et al., 2006).

\section{Measurement of primary and secondary response}

The primary and secondary responses i.e. paw volume of the ipsilateral and contralateral hind paw of each rat was measured alternate days by using liquid displacement plethysmometer. Increase in the extent of erythema and edema of the tissues shows the severity of the inflammation. The severity of arthritis was recorded by a blinded observer using the visual arthritis scoring system (Kumar et al., 2006). The arthritis score ranged from 0 to $4 ; 0$ indicates the least but definite swelling and 4 represent the maximum swelling. This scoring systems involves observations of all four paws and giving a separate score for each limb. Scores were assigned for evaluation of the pain associated with arthritis as shown in table-I. The difference in the severity of arthritis between the treatment groups and the arthritic group were statistically analyzed.

\section{Evaluation of Mechanical Hyperalgesia}

The anti-nociceptive activity was carried out by the method described by $\mathrm{Yu}$ and his co writers with some modifications (Yu et al., 2002). Measurement included the vocalization threshold of the tibiotarsal joint compression. The vocalization threshold of the joint compression was measured by using a pair of large blunt forceps $(20 \mathrm{~cm}$ long; contact area $4 \mathrm{~mm} \mathrm{X}$ $4 \mathrm{~mm}$ ) equipped with strain gauges, which produce an output voltage that was potential to the applied force. The threshold was determined by applying increasing pressure to the tibiotarsal joint until an audible squeak was elicited. The output voltage, which was calibrated to grams of force using a known weight suspended by a string, was read at the time of vocalization. Since the repeated application of pressure in the short intervals may sensitize the joint, a measurement was made once at each time point on every alternate day.

\section{Assessment of Neuromuscular coordination}

Neuromuscular coordination was assessed using the Rotarod test. The experimental procedure was described elsewhere (Dunhan, Miya, 1957). Briefly, the duration (s) that threats stayed on a rotating rod (diameter, $10 \mathrm{~cm} ; 20 \mathrm{rpm}$ ) was recorded in each case for up to $180 \mathrm{~s}$. The trial was conducted five times for each rat, and the mean riding time was used as the mean value for this test. When the duration of riding was over $180 \mathrm{~s}$, the rat was released from the rod, and the riding time was recorded for every alternative day.

TABLE I- Scoring system for evaluation of the pain associated with FCA induced arthritic rats

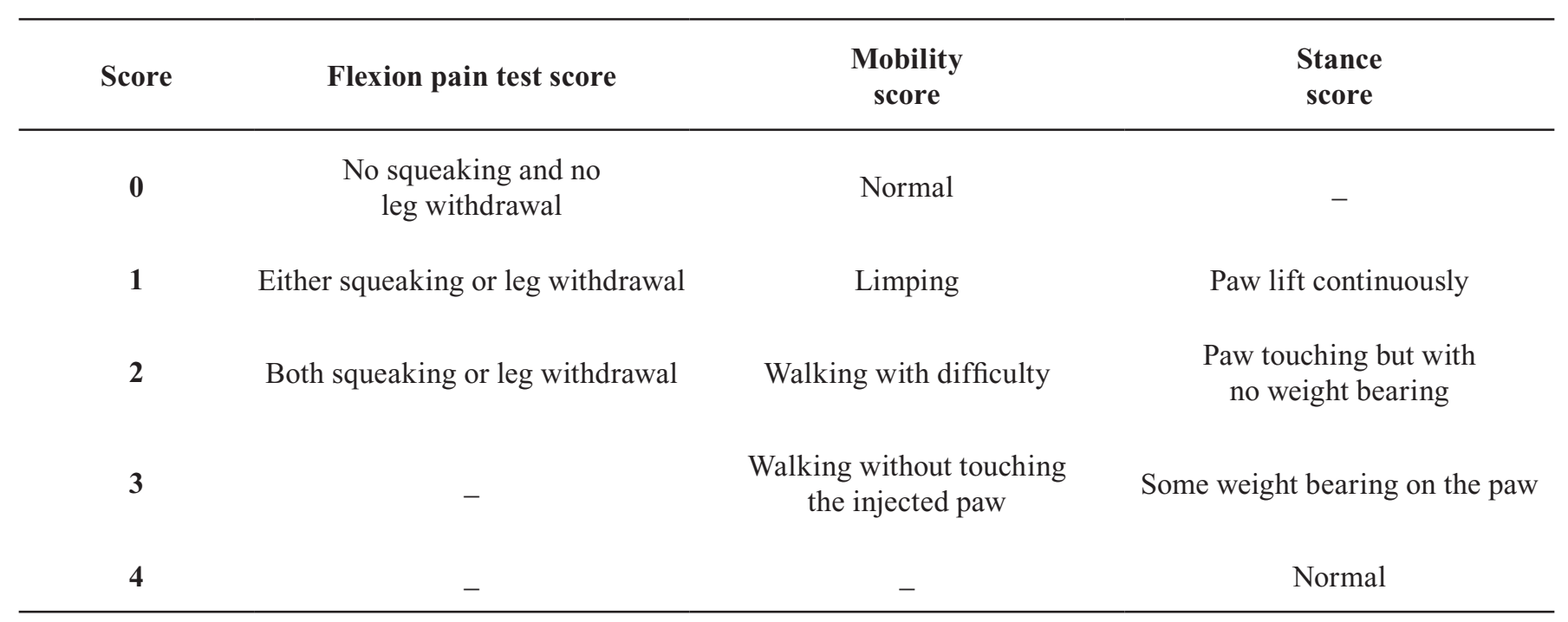




\section{Assessment of Anti-depressant activity}

The antidepressant activity was assessed by using Forced swimming test (FST) on every alternate day. It is the most widely used and recognized pharmacological model for assessing anti-depressant activity (Porsolt et al., 1977). The development of immobility when the rats are placed in an inescapable cylinder filled with water reflects the cessation of persistent escape-directed behavior. The apparatus consisted of a clear Plexiglas cylinder (20 cm high $\times 12 \mathrm{~cm}$ diameter) filled to a 15 $\mathrm{cm}$ depth with water. In the pre-test session, every animal was placed individually into the cylinder for $15 \mathrm{~min}, 24 \mathrm{~h}$ prior to the $5 \mathrm{~min}$ swimming test. During the test session the following behavioral responses were recorded: climbing behavior, which is defined as upward-directed movements of the forepaws along the side of the swim chamber; swimming behavior, defined as movement throughout the swim chamber, which include crossing into another quadrant; and immobility time, that was considered when the rat made no further attempts to escape, and makes only the movements to keep its head above the water.

\section{Changes in Bodyweight, Spleen, and Thymus weight}

Body weight of each rat in all groups was measured on every alternate day till continuation of the treatment using a weighing balance and the changes were recorded. At the end of the study, the animals were sacrificed with an over dose of anesthetic ether. The thymus and spleen of all the animals were removed and changes in their weight were measured by using the digital balance.

\section{Hematological parameters}

On the day of sacrification blood was collected by retro-orbital plexus for examining the following hematological parameters. Hemoglobin $(\mathrm{Hb})$, Red blood cell count (RBC), White blood cell count (WBC), Lymphocyte count and Mean corpuscular Hemoglobin concentration (MCHC) were analyzed by using hematological auto-analyzer (Mindray BC-2800). Erythrocyte sedimentation rate (ESR) and packed cell volume (PCV) (Ghai, 1993) were determined by the usual standardized laboratory method.

\section{Serological parameters}

The level of serum inflammation and arthritis markers like C-reactive protein (CRP) (Yong, 1995) and rheumatoid factor (RF) (Bandila, Mcduffie, 1969) was determined by using commercial kits according to the manufacturer's instructions.

\section{Serum Biochemical parameters}

The level of serum aspartate aminotransferase (AST) (Sllaie, 1991), alanine aminotransferase (ALT), alkaline phosphatase (ALP) (GSCC, 1970) total cholesterol, triglycerides, albumin (Rifai, 1997), urea and creatinine were assessed by using marketed kits.

\section{Radiographic analysis}

On $21^{\text {st }}$ day animals were anesthetized with anesthetic ether and placed an X-ray machine for the radiographic analysis of the tibiotarsal joint. X-ray was taken at the joint of the contralateral paw for the confirmation of the severity of arthritis in FCA induced rats.

\section{Estimation of brain neurotransmitters}

On the day of scarification, animals were sacrificed by cervical decapitation the whole brain was rapidly removed weighed, homogenized and prepared for brain biogenic amines noradrenaline (NA) and serotonin (5HT) was estimated by spectrofluorimetric micro method (Schlumpf et al., 1974).

\section{Histopathology}

All the animals were sacrificed at the end of the experiments. Left hind paws were removed of all the animals and post fixed in formal saline ( 7 days) and then decalcified in 5\% formic acid. Joints were then trimmed, embedded and sectioned at $6 \mu \mathrm{m}$. Sections were then stained with hematoxylin and eosin and were examined microscopically for histopathological changes.

\section{Statistical analysis}

The data represents a mean \pm SEM of six replicated determinations. Results were analyzed statistically by one way ANOVA followed by post hoc Dunnet's test for 
normal data and by the Kruskal-Wallis test followed by Dunnet's multiple comparisons for the scored data using SPSS V.17 (Student trial version). The difference was considered significant when $\mathrm{p}<0.05$.

\section{RESULTS AND DISCUSSION}

FCA induced arthritis is the widely used model of human rheumatoid arthritis because this model of arthritis resembles RA in certain clinical and histological aspect (Pearson, Wood, 1963). FCA is the complete form of Freud's adjuvant and is composed of inactivated and dried Mycobacterium tuberculosis (MT) emulsified in mineral oil that is used as an immune- booster. Injection of FCA in the hind paw is effective in stimulating the cell- mediated immunity and may lead to the potentiation of the production of certain immunoglobulins (Ig) to produce primary and secondary chronic arthritis (Walz et al., 1971). Based on this mechanical approach the FCA induced RA rat model was developed successfully in this study.

After FCA injection on the right hind paw initial reaction (Primary lesions) of edema and soft tissue thickening developed at the depot site by the irritant effect of the adjuvant, whereas the last phase arthritis and flare in the injected foot are presumed to immunological events. The occurrence of the secondary lesion (swelling in the non-injected paw) characterized by tibiotarsal joint swelling and nodules formation in the tail is a manifestation of cell-mediated immunity. Chronic inflammation involves the release of the number of inflammatory mediators like pro-inflammatory cytokines (IL-1 $\beta$ and TNF- $\alpha$ ), interferons, GM-CSF (Granulocytes- macrophage colony-stimulating factor) and platelet-derived growth factor (PGDF). These types of mediators are responsible for the pain (hyperalgesia), destruction of bone and cartilage can lead to severe disability (Eric, Lawrence, 1996). It appears from our findings that the leflunomide $12 \mathrm{mg} / \mathrm{kg}$ alone (LEF), leflunomide $12 \mathrm{mg} / \mathrm{kg}$ with Low dose amitriptyline 9 $\mathrm{mg} / \mathrm{kg}$ (LELA) and leflunomide $12 \mathrm{mg} / \mathrm{kg}$ with High dose amitriptyline $18 \mathrm{mg} / \mathrm{kg}$ (LEHA) treatment group were significantly $(\mathrm{p}<0.001)$ reduced the primary and secondary lesions. When the comparison was made between these treatments LELA treated group possess more significant action in the early stages of therapy itself. It may be due to the inhibiting the release of inflammatory cells. LEF treatment group on day 21 significantly $(\mathrm{p}<0.001)$ reduced both the paw volume as compare to the arthritic control but it remains significant $(p<0.001)$ swelling as compared to vehicle control (Table II and III).

TABLE II- Effect of leflunomide and amitriptyline against Freund's complete adjuvant induced paw edema on ipselateral paw (Primary lesions)

\begin{tabular}{|c|c|c|c|c|c|}
\hline \multirow{2}{*}{$\begin{array}{l}\text { Post insult time } \\
\text { in days }\end{array}$} & \multicolumn{5}{|c|}{ Mean changes in swelling volume $(\mathrm{ml}) \pm \mathrm{SEM}$ on injected paw } \\
\hline & $\begin{array}{c}\text { Group-I } \\
\text { (Vehicle con.) }\end{array}$ & $\begin{array}{l}\text { Group-II } \\
\text { (Arth con.) }\end{array}$ & $\begin{array}{l}\text { Group-III } \\
\text { (LEF) }\end{array}$ & $\begin{array}{l}\text { Group- IV } \\
\text { (LELA) }\end{array}$ & $\begin{array}{c}\text { Group- V } \\
\text { (LEHA) }\end{array}$ \\
\hline 0 & $0.42 \pm 0.01$ & $0.40 \pm 0.12$ & $0.41 \pm 0.02$ & $0.40 \pm 0.01$ & $0.40 \pm 0.01$ \\
\hline 3 & $0.43 \pm 0.01$ & $0.71 \pm 0.02 \mathrm{a}^{* * *}$ & $0.68 \pm 0.01 \mathrm{a}^{* * *}$ & $0.71 \pm 0.02 \mathrm{a}^{* * *}$ & $0.73 \pm 0.02 \mathrm{a}^{* * *}$ \\
\hline 5 & $0.44 \pm 0.01$ & $0.77 \pm 0.03 \mathrm{a}^{* * *}$ & $0.74 \pm 0.01 \mathrm{a}^{* * *}$ & $0.75 \pm 0.03 \mathrm{a}^{* * *}$ & $0.76 \pm 0.02 \mathrm{a}^{* * *}$ \\
\hline
\end{tabular}


TABLE II- Effect of leflunomide and amitriptyline against Freund's complete adjuvant induced paw edema on ipselateral paw (Primary lesions)

\begin{tabular}{|c|c|c|c|c|c|}
\hline \multirow{2}{*}{$\begin{array}{l}\text { Post insult time } \\
\text { in days }\end{array}$} & \multicolumn{5}{|c|}{ Mean changes in swelling volume $(\mathrm{ml}) \pm \mathrm{SEM}$ on injected paw } \\
\hline & $\begin{array}{c}\text { Group-I } \\
\text { (Vehicle con.) }\end{array}$ & $\begin{array}{l}\text { Group-II } \\
\text { (Arth con.) }\end{array}$ & $\begin{array}{l}\text { Group-III } \\
\text { (LEF) }\end{array}$ & $\begin{array}{l}\text { Group- IV } \\
\text { (LELA) }\end{array}$ & $\begin{array}{c}\text { Group- V } \\
\text { (LEHA) }\end{array}$ \\
\hline 14 & $0.48 \pm 0.01$ & $\begin{array}{c}0.85 \pm 0.02 \\
a^{* * *}\end{array}$ & $\begin{array}{c}0.81 \pm 0.02 \\
\mathrm{a}^{* * *}\end{array}$ & $\begin{array}{c}0.72 \pm 0.03 \\
a^{* * *} b^{* *}\end{array}$ & $\begin{array}{c}0.75 \pm 0.02 \\
a^{* * *} b^{*}\end{array}$ \\
\hline 19 & $0.49 \pm 0.003$ & $\begin{array}{c}0.78 \pm 0.04 \\
\mathrm{a}^{* * *}\end{array}$ & $\begin{array}{c}0.72 \pm 0.01 \\
\mathrm{a}^{* * *}\end{array}$ & $\begin{array}{c}0.63 \pm 0.02 \\
a^{* * *} b^{* *}\end{array}$ & $\begin{array}{c}0.67 \pm 0.01 \\
a^{* * *} b^{*}\end{array}$ \\
\hline 21 & $0.49 \pm 0.01$ & $\begin{array}{c}0.82 \pm 0.02 \\
\mathrm{a}^{* * *}\end{array}$ & $\begin{array}{l}0.68 \pm 0.02 \\
a^{* * *} b^{* * *}\end{array}$ & $\begin{array}{c}0.54 \pm 0.01 \\
\mathrm{~b}^{* * *}\end{array}$ & $\begin{array}{c}0.60 \pm 0.01 \\
a^{* *} b^{* * *}\end{array}$ \\
\hline
\end{tabular}

Values are expressed as mean \pm SEM, $\mathrm{n}=6$. Comparisons were made between:

a - Group I vs II, III, IV and V.

b - Group II vs III, IV and V

Symbols represent statistical significance:

$* * *$ - $\mathrm{p}<0.001$,

$* *-p<0.01$

$*-p<0.05$

TABLE III - Effect of leflunomide and amitriptyline against Freund's complete adjuvant induced paw edema on contra lateral paw (secondary lesions)

Mean changes in swelling volume $(\mathrm{ml}) \pm \mathrm{SEM}$ on injected paw

\begin{tabular}{|c|c|c|c|c|c|}
\hline \multirow{2}{*}{$\begin{array}{l}\text { Post insult time } \\
\text { in days }\end{array}$} & \\
\hline & $\begin{array}{c}\text { Group-I } \\
\text { (Vehicle con.) }\end{array}$ & $\begin{array}{l}\text { Group-II } \\
\text { (Arth. con.) }\end{array}$ & $\begin{array}{l}\text { Group-III } \\
\text { (LEF) }\end{array}$ & $\begin{array}{l}\text { Group- IV } \\
\text { (LELA) }\end{array}$ & $\begin{array}{c}\text { Group-V } \\
\text { (LEHA) }\end{array}$ \\
\hline 1 & $0.41 \pm 0.01$ & $0.43 \pm 0.003$ & $0.40 \pm 0.02$ & $0.40 \pm 0.02$ & $0.41 \pm 0.01$ \\
\hline 5 & $0.43 \pm 0.01$ & $0.45 \pm 0.02$ & $0.48 \pm 0.02$ & $0.48 \pm 0.01$ & $0.46 \pm 0.01$ \\
\hline 7 & $0.44 \pm 0.01$ & $\begin{array}{c}0.65 \pm 0.02 \\
a^{* * *}\end{array}$ & $\begin{array}{c}0.65 \pm 0.02 \\
a^{* * *}\end{array}$ & $\begin{array}{c}0.64 \pm 0.02 \\
a^{* * *}\end{array}$ & $\begin{array}{c}0.63 \pm 0.01 \\
a^{* * *}\end{array}$ \\
\hline 9 & $0.45 \pm 0.01$ & $\begin{array}{c}0.70 \pm 0.02 \\
\mathrm{a}^{* * *}\end{array}$ & $\begin{array}{c}0.69 \pm 0.02 \\
a^{* * *}\end{array}$ & $\begin{array}{c}0.67 \pm 0.02 \\
a^{* * *}\end{array}$ & $\begin{array}{c}0.70 \pm 0.02 \\
\mathrm{a}^{* * *}\end{array}$ \\
\hline 14 & $0.45 \pm 0.02$ & $\begin{array}{c}0.73 \pm 0.01 \\
a^{* * *}\end{array}$ & $\begin{array}{c}0.66 \pm 0.02 \\
a^{* * *}\end{array}$ & $\begin{array}{c}0.59 \pm 0.02 \\
a^{* * *} b^{* *}\end{array}$ & $\begin{array}{c}0.62 \pm 0.02 \\
a^{* * *} b^{* *}\end{array}$ \\
\hline
\end{tabular}


TABLE III - Effect of leflunomide and amitriptyline against Freund's complete adjuvant induced paw edema on contra lateral paw (secondary lesions)

\begin{tabular}{cccccc}
\hline \multirow{2}{*}{$\begin{array}{c}\text { Post insult time } \\
\text { in days }\end{array}$} & $\begin{array}{c}\text { Mean changes in swelling volume (mI) } \pm \text { SEM on injected paw } \\
\text { (Vehicle con.) }\end{array}$ & $\begin{array}{c}\text { Group-II } \\
\text { (Arth. con.) }\end{array}$ & $\begin{array}{c}\text { Group-III } \\
\text { (LEF) }\end{array}$ & $\begin{array}{c}\text { Group- IV } \\
\text { (LELA) }\end{array}$ & $\begin{array}{c}\text { Group-V } \\
\text { (LEHA) }\end{array}$ \\
\cline { 2 - 6 } & $0.48 \pm 0.01$ & $\begin{array}{c}0.75 \pm 0.02 \\
\mathrm{a}^{* * *}\end{array}$ & $\begin{array}{c}0.64 \pm 0.03 \\
\mathrm{a}^{* * *} \mathrm{~b}^{*}\end{array}$ & $\begin{array}{c}0.53 \pm 0.02 \\
\mathrm{~b}^{* * *}\end{array}$ & $\begin{array}{c}0.60 \pm 0.02 \\
\mathrm{a}^{* *} \mathrm{~b}^{* *}\end{array}$ \\
\hline 19 & $0.48 \pm 0.01$ & $\begin{array}{c}0.78 \pm 0.01 \\
\mathrm{a}^{* * *}\end{array}$ & $\begin{array}{c}0.63 \pm 0.03 \\
\mathrm{a}^{* * *} \mathrm{~b}^{* * *}\end{array}$ & $\begin{array}{c}0.50 \pm 0.01 \\
\mathrm{~b}^{* * *}\end{array}$ & $\begin{array}{c}0.58 \pm 0.03 \\
\mathrm{a}^{* *} \mathrm{~b}^{* * *}\end{array}$ \\
\hline
\end{tabular}

Values are expressed as mean $\pm \mathrm{SEM}, \mathrm{n}=6$. Comparisons were made between:

a - Group I vs II, III, IV and V.

b - Group II vs III, IV and V

Symbols represent statistical significance:

$* * *$ - $p<0.001$,

$* *-\mathrm{p}<0.01$

$*-\mathrm{p}<0.05$

Arthritis index in the visual arthritis scoring system was assigned for evaluating the pain associated with arthritis and functional impairment in arthritis. In this study the arthritic score was significantly decreased in the entire treatment group as compared to arthritic control, it revealed the significant reduction of arthritis in the leflunomide alone and combination with amitriptyline treated group. LELA treated group significantly increases the pain threshold and reduce the flexion pain test score. Furthermore the leflunomide and amitriptyline combination-treated group lowered the mobility score and improved the stance score indicating the reduction in pain and functional impairments in arthritic rats (Table IV).

TABLE IV- Effect on arthritic pain index

\begin{tabular}{lcccc}
\hline Treatment Groups & $\begin{array}{c}\text { Arthritis } \\
\text { score }\end{array}$ & Flexion pain test score & Mobility score & Stance score \\
\hline Arthritic control & $11.5(9,13)$ & $2.0(1,2)$ & $3.0(2,3)$ & $1.0(1,2)$ \\
LEF & $5.5(4,8)^{* *}$ & $1.5(1,2)$ & $2.5(1,3)$ & $2.5(2,4)$ \\
LELA & $3.0(2,5)^{* * *}$ & $1(0,1) *$ & $1.0(0,1)^{* *}$ & $4.0(2,4) * *$ \\
LEHA & $4.0(3,6)^{* * *}$ & $1.25(0,2)$ & $1.5(1,2)^{*}$ & $3.0(2,4)^{*}$ \\
\hline
\end{tabular}

Values were represented in median (minimum, maximum), $n=6$. Comparisons were made between: Arthritic control vs LEF, LELA and LEHA

Symbols represent statistical significance:

$* * *$ - $\mathrm{p}<0.001$,

$* *-\mathrm{p}<0.01$,

$*-\mathrm{p}<0.05$ 
Hyperalgesia is an important system associated with an arthritic condition. It is mediated through PGs and other endogenous mediators (Pedernera et al., 2006). Tenderness of joint and decreased in weight-bearing is the major symptom of arthritis (Gilliland, 1990). So the pain threshold for joint compression might be a useful way to represent the levels of tenderness in the joint ( $\mathrm{Yu}$ et al., 2002). Table V and VI portrayed that the normal rat hind paw compressed with nearly ( $290 \mathrm{gm})$ of force before elucidating a painful reflex. However, this paw withdrawal threshold declined drastically after the induction of arthritis. So that compression of the joint with a weak force about (100 gm) could elicit a pain response. After the therapy, the paw with drawl threshold was elevated significantly on 6 days in the leflunomide and amitriptyline combination-treated group, but there are no significant changes in the leflunomide alone treated group. On the $21^{\text {st }}$ day the entire treatment group showed significant increases in paw withdrawal threshold as compared to arthritic control in the comparison between this treatment groups, LELA showed more significantly elevate the lowered threshold towards the normal value.

TABLE V-Effect of leflunomide and amitriptyline on mechanical hyperalgesia in the ipselateral paw

Paw withdrawal threshold (g)

\section{Groups}

Day 0

Day 3

Day 9

Day 14

Day 21

Group I

(Vehicle.con)

$280.44 \pm 4.77$

$275.47 \pm 4.88$

$250 \pm 4.23$

$238.92 \pm 7.10$

$240.41 \pm 5.79$

Group II

(Arth.con)

$276.75 \pm 8.29$

$171.04 \pm 9.15$
$a^{* * *}$

$113.34 \pm 6.42$
$\mathrm{a}^{* * *}$

$99.28 \pm 6.72$

$a^{* * *}$

$96.35 \pm 4.71$
$a^{* * *}$

Group III

(LEF)

$280.02 \pm 4.94$

$168.92 \pm 11.4$

$110.67 \pm 8.22$

$\mathrm{a}^{* * *}$

$120 \pm 7.47$

$146.78 \pm 4.87$

$\mathrm{a}^{* * *}$

$\mathrm{a}^{* * *}$

$a^{* * *} b^{* *}$

Group IV

(LELA)

$281.56 \pm 7.35$

$167.24 \pm 10.05$

$\mathrm{a}^{* * *}$

$115.42 \pm 6.51$

$138 \pm 5.87$

$\mathrm{a}^{* * *}$

$\mathrm{a}^{* * *} \mathrm{~b}^{* *}$

$203.02 \pm 8.15$

$a^{* *} b^{* * *}$

Group V

(LEHA)

$277.38 \pm 8.67$

$171.41 \pm 12.80$

$108.42 \pm 4.66$

$125 \pm 3.25$

$188.44 \pm 10.42$

$\mathrm{a}^{* * *}$

$\mathrm{a}^{* * *}$

$\mathrm{a}^{* * *} \mathrm{~b}^{*}$

$a^{* * *} b^{* * *}$

Values are expressed as mean $\pm \mathrm{SEM}, \mathrm{n}=6$. Comparisons were made between:

a - Group I vs II, III, IV and V.

b - Group II vs III, IV and V

Symbols represent statistical significance:

$* * *$ - $\mathrm{p}<0.001$,

$* *-\mathrm{p}<0.01$

$*-p<0.05$ 
TABLE VI- Effect of leflunomide and amitriptyline on mechanical hyperalgesia in the contra lateral paw

\begin{tabular}{|c|c|c|c|c|}
\hline \multirow{2}{*}{ Group } & \multicolumn{4}{|c|}{ Paw withdrawal threshold (g) } \\
\hline & Day 5 & Day 9 & Day 14 & Day 21 \\
\hline $\begin{array}{l}\text { Group I } \\
\text { (Vehicle.con) }\end{array}$ & $260.71 \pm 6.01$ & $255.14 \pm 4.11$ & $247.26 \pm 4.21$ & $242.78 \pm 6.67$ \\
\hline $\begin{array}{l}\text { Group II } \\
\text { (Arth.con) }\end{array}$ & $204.67 \pm 7.59$ & $\begin{array}{c}138.56 \pm 5.20 \\
a^{* * *}\end{array}$ & $\begin{array}{c}120.64 \pm 5.17 \\
\mathrm{a}^{* * *}\end{array}$ & $\begin{array}{c}107.13 \pm 9.19 \\
\mathrm{a}^{* * *}\end{array}$ \\
\hline $\begin{array}{l}\text { Group III } \\
\text { (LEF) }\end{array}$ & $207.24 \pm 11.44$ & $\begin{array}{c}136.45 \pm 5.94 \\
a^{* * *}\end{array}$ & $\begin{array}{c}142.14 \pm 7.75 \\
a^{* * *}\end{array}$ & $\begin{array}{c}157.24 \pm 5.34 \\
a^{* * *} b^{* *}\end{array}$ \\
\hline $\begin{array}{l}\text { Group IV } \\
\text { (LELA) }\end{array}$ & $207.53 \pm 7.79$ & $\begin{array}{c}141.02 \pm 6.65 \\
a^{* * *}\end{array}$ & $\begin{array}{c}176.41 \pm 7.47 \\
a^{* * *} b^{* * *}\end{array}$ & $\begin{array}{c}206.48 \pm 9.47 \\
a^{*} b^{* * *}\end{array}$ \\
\hline $\begin{array}{l}\text { Group V } \\
\text { (LEHA) }\end{array}$ & $202.47 \pm 12.31$ & $\begin{array}{c}137.12 \pm 5.33 \\
\mathrm{a}^{* * *}\end{array}$ & $\begin{array}{c}155.06 \pm 4.59 \\
\mathrm{a}^{* * *} \mathrm{~b}^{* *}\end{array}$ & $\begin{array}{c}180.03 \pm 7.16 \\
\mathrm{a}^{* * *} \mathrm{~b}^{* * *}\end{array}$ \\
\hline
\end{tabular}

Values are expressed as mean \pm SEM, $\mathrm{n}=6$. Comparisons were made between:

a - Group I vs II, III, IV and V.

b - Group II vs III, IV and V

Symbols represent statistical significance:

$* * *$ - $\mathrm{p}<0.001$,

$* *-\mathrm{p}<0.01$

$*-\mathrm{p}<0.05$

The muscle weakness in the patient with RA has long been recognized. Muscle relaxation in RA patient is generally attributed to a reflex response to pain, joint deformation and/or psychological factor. Mizoguchi et al., (2002) suggested that the impairment of rota rod performance is caused by depression is due to the reduction of dopaminergic and serotonergic transmission in the prefrontal cortex (PFC). The present results indicate that the leflunomide and amitriptyline combination-treated groups more significantly increase the riding time during the earlier day of starting therapy as compared to the arthritic control, but leflunomide alone shows a less significant reduction in the riding time on $21^{\text {st }}$ day. From this leflunomide and amitriptyline combination therapy shows more significantly increases the muscle strength and motor coordination in FCA induced arthritic rats (Table VII).

Forced swimming test is the behavioral model for evaluating antidepressant drugs. The increased immobility displays the state of despair in animals, which is claimed to reproduce a condition similar to human depression. The main symptoms of depression were due to the functional deficiency of cerebral monoaminergic transmitter such as serotonin, norepinephrine and/ or dopamine located at synapses (Schildkraut, 1965). In this study, arthritic rats showed a more significant duration of immobility which represents that arthritis is associated with depression. This depressive state was reverted by the treatment of leflunomide combination with amitriptyline; it also significantly increases the locomotor activity as compared to vehicle control. But in leflunomide alone treated group shows a less significant reduction in duration of immobility, and also it possesses significant depressive symptom. In comparison between these treated groups LEHA possess more antidepressant activity (Table VIII). 
TABLE VII-Effect of leflunomide and amitriptyline on neuromuscular coordination in FCA induced arthritic rats

\begin{tabular}{|c|c|c|c|c|c|}
\hline \multirow{2}{*}{ Group } & \multicolumn{5}{|c|}{ Riding time (sec) } \\
\hline & Day 0 & Day 1 & Day 9 & Day 14 & Day 21 \\
\hline $\begin{array}{l}\text { Group I } \\
\text { (Vehicle.con) }\end{array}$ & $58.8 \pm 1.37$ & $65.8 \pm 1.11$ & $62.5 \pm 1.71$ & $63.25 \pm 1.25$ & $63.5 \pm 1.94$ \\
\hline $\begin{array}{l}\text { Group II } \\
\text { (Arth.con) }\end{array}$ & $59.3 \pm 1.93$ & $\begin{array}{c}46.3 \pm 1.49 \\
a^{* * *}\end{array}$ & $\begin{array}{c}25.0 \pm 1.08 \\
a^{* * *}\end{array}$ & $\begin{array}{c}22.5 \pm 1.19 \\
a^{* * *}\end{array}$ & $18.8 \pm 1.65$ \\
\hline $\begin{array}{l}\text { Group III } \\
\text { (LEF) }\end{array}$ & $62.5 \pm 1.7$ & $\begin{array}{c}49.0 \pm 2.04 \\
\mathrm{a}^{* * *}\end{array}$ & $\begin{array}{c}25.5 \pm 1.44 \\
a^{* * *}\end{array}$ & $\begin{array}{c}28.0 \pm 1.68 \\
a^{* * *}\end{array}$ & $\begin{array}{c}29.3 \pm 1.11 \\
a^{* * *} b^{*}\end{array}$ \\
\hline $\begin{array}{l}\text { Group IV } \\
\text { (LELA) }\end{array}$ & $61.3 \pm 3.30$ & $\begin{array}{c}50.0 \pm 1.08 \\
a^{* * *}\end{array}$ & $\begin{array}{c}24.8 \pm 1.49 \\
a^{* * *}\end{array}$ & $\begin{array}{l}45.3 \pm 1.49 \\
a^{* * *} b^{* * *}\end{array}$ & $\begin{array}{c}52.8 \pm 3.43 \\
a^{*} b^{* * *}\end{array}$ \\
\hline $\begin{array}{l}\text { Group V } \\
\text { (LEHA) }\end{array}$ & $59.5 \pm 1.3$ & $\begin{array}{c}46.3 \pm 1.38 \\
a^{* * *}\end{array}$ & $\begin{array}{c}26.3 \pm 1.25 \\
\mathrm{a}^{* * *}\end{array}$ & $\begin{array}{l}42.5 \pm 1.04 \\
a^{* * *} b^{* * *}\end{array}$ & $\begin{array}{l}47.0 \pm 1.47 \\
a^{* * *} b^{* * *}\end{array}$ \\
\hline
\end{tabular}

Values are expressed as mean $\pm \mathrm{SEM}, \mathrm{n}=6$. Comparisons were made between:

a - Group I vs II, III, IV and V.

b - Group II vs III, IV and V

Symbols represent statistical significance:

$* * *$ - $p<0.001$,

$* *-p<0.01$

$*-\mathrm{p}<0.05$

In arthritic condition decrease in body weight due to the deficient absorption of nutrients through the intestine and increased production of pro-inflammatory cytokines such as TNF- $\alpha$ and Interleukin-1 (Roubenoff et al., 1997). Treatment with LELA shows significant $(\mathrm{p}<0.01)$ increase in body weight as compared to another treatment group. The reduction in spleen and increase in thymus weight are related to a stimulatory effect on the immune system (Pedernera et al., 2006). The observed decrease in the spleen and thymus weight in all the treatment groups indicates alteration of the cell population in these organs, which are related to the immune function. It could be attributed to the antiproliferative action of leflunomide and amitriptyline. Among the treatment groups LELA treated group has more antiproliferative action in these organs (Table IX).

Similarly arthritic condition is associated with moderate decreases in $\mathrm{RBC}, \mathrm{Hb}$ and $\mathrm{MCHC}$ represent the anemic symptom in rats (Agarwal, Rangari, 2003).
Hypochronic and normocytic anemia is generally seen in arthritic condition and it is due to the reduction in the $\mathrm{RBC}$ count with a modest reduction in the MCHC and $\mathrm{PCV}$. The most important causes of anemia in adjuvant arthritis might be the decreased level of plasma iron due to sequestering of iron in the reticuloendothelial system and synovial tissue leads to failure of bone marrow to respond anemia. This decreased in plasma iron intern was induced by IL-1 is associated with the acute inflammatory response. Reduction in the $\mathrm{Hb}$ during arthritis is due to the reduced erythropoietin level, a decreased response of the bone marrow erythropoietin and premature destruction of red blood cell (Mowat, 1971). The present study results confirm the decreased level of RBC count, $\mathrm{Hb}, \mathrm{MCHC}$ and $\mathrm{PCV}$ in arthritic condition, where as significant increase was observed in all the treatment groups, among that leflunomide and amitriptyline combination treatment shown more significant increases as compared to the leflunomide alone treatment (Table X). 
TABLE VIII- Effect of leflunomide and amitriptyline on the duration of immobility in the forced swimming test

\begin{tabular}{|c|c|c|c|c|c|}
\hline \multirow{2}{*}{ Group } & \multicolumn{5}{|c|}{ Duration of immobility (sec) } \\
\hline & Day 0 & Day 3 & Day 9 & Day 14 & Day 21 \\
\hline $\begin{array}{l}\text { Group I } \\
\text { (vehicle.con) }\end{array}$ & $155.22 \pm 2.86$ & $158.40 \pm 2.10$ & $154.20 \pm 2.71$ & $151.32 \pm 2.86$ & $169.21 \pm 4.34$ \\
\hline $\begin{array}{l}\text { Group II } \\
\text { (Arth.con) }\end{array}$ & $150.24 \pm 5.01$ & $\begin{array}{c}114.40 \pm 3.97 \\
a^{* * *}\end{array}$ & $\begin{array}{c}205.62 \pm 2.50 \\
a^{* * *}\end{array}$ & $\begin{array}{c}196.24 \pm 4.61 \\
a^{* * *}\end{array}$ & $\begin{array}{c}203.11 \pm 3.71 \\
a^{* * *}\end{array}$ \\
\hline $\begin{array}{l}\text { Group III } \\
\text { (LEF) }\end{array}$ & $156.41 \pm 3.43$ & $\begin{array}{c}115.14 \pm 2.27 \\
\mathrm{a}^{* * *}\end{array}$ & $\begin{array}{c}199.43 \pm 5.18 \\
a^{* * *}\end{array}$ & $\begin{array}{c}182.74 \pm 1.89 \\
a^{* * *} b^{*}\end{array}$ & $\begin{array}{c}185.23 \pm 5.01 \\
a^{*} b^{*}\end{array}$ \\
\hline $\begin{array}{l}\text { Group IV } \\
\text { (LELA) }\end{array}$ & $157.34 \pm 3.01$ & $\begin{array}{c}121.64 \pm 2.5 \\
a^{* * *}\end{array}$ & $\begin{array}{c}204.12 \pm 2.10 \\
\mathrm{a}^{* * *}\end{array}$ & $\begin{array}{c}160.70 \pm 3.23 \\
\mathrm{~b}^{* * *}\end{array}$ & $\begin{array}{c}134.57 \pm 2.10 \\
a^{* * *} b^{* * *}\end{array}$ \\
\hline $\begin{array}{l}\text { Group V } \\
\text { (LEHA) }\end{array}$ & $156.21 \pm 4.64$ & $\begin{array}{c}121.42 \pm 4.78 \\
a^{* * *}\end{array}$ & $\begin{array}{c}204.47 \pm 4.29 \\
a^{* * *}\end{array}$ & $\begin{array}{c}135.00 \pm 2.38 \\
a^{* *} b^{* * *}\end{array}$ & $\begin{array}{c}117.12 \pm 3.24 \\
a^{* * *} b^{* * *}\end{array}$ \\
\hline
\end{tabular}

Values are expressed as mean $\pm \mathrm{SEM}, \mathrm{n}=6$. Comparisons were made between:

a - Group I vs II, III, IV and V.

b - Group II vs III, IV and V

Symbols represent statistical significance:

$* * *$ - $p<0.001$,

$* *-p<0.01$

$*-\mathrm{p}<0.05$

ESR is an indirect measurement of acute phase response for determining the RA disease activity. The ESR attributed to the accelerated formation of endogenous proteins such as fibrinogen and $\alpha / \beta$ globulin, the increased level of ESR indicating the chronicity and severity of the disease activity (Marcelletti, Nakamura, 2003). The increased ESR level in arthritic condition was brought back by the leflunomide and amitriptyline combination- treated groups, but there were no significant changes in leflunomide alone treated the group as compared to the arthritic control (Table X).

In arthritic condition there will be mild to moderate rise in WBC count was observed due to the release of IL-1 $\beta$ inflammatory response. IL-1 $\beta$ increases the production of both granulocytes and macrophages colony-stimulating factor (William, 1996).Lymphocyte count also elevated in arthritic condition, because T-lymphocytes have been reported to play a central role in the pathogenesis of RA (Agarwal, Rangari,
2003). In this study reveals that all the treatment group significantly revert the elevated WBC and Lymphocyte count. The above-mentioned changes were more significantly $(p<0.001)$ brought back to near normal level upon the LELA treatment, which emphasizes the beneficial effect of LELA combination on FCA induced arthritic rats (Table $\mathrm{X}$ ).

The serum C-reactive protein (CRP) and rheumatoid factor (RF) are markers of systemic inflammation and antibody production against the injected FCA. CRP is a member of the acute phase reactant and its level raised dramatically during inflammation (Mc Conkey et al., 1973). Serum RF is the immunological expression of an individual immune system reaction to the presence of an immunoglobulin that is recognized as nonself. Increased serum level of RF is due to the higher development of inflammation (Koopman, 1990). In this study leflunomide and amitriptyline combination treatment groups showed a significant reduction of both 
serum CRP and RF in the early stages of the treatment itself. But leflunomide alone treated group requires some time to show action, it showed a significant reduction on day $21^{\text {st }}$. In comparison between these treatments, LELA treated group shown more significant and faster action on this biomarker of inflammation and autoimmune stimulation in FCA induced arthritic rats (Table XI).

Assessment of the serum level of AST, ALT, and ALP provides an excellent and simple tool to measure the Anti-arthritic activity of targeted drugs. The activities of aminotransferases and ALP increased significantly in arthritic rats (Rainsford, 1982). Serum AST and ALT have been reported to play a vital role in the formation of biologically active chemical mediators such as bradykinin in the inflammatory process. The elevated level of serum ALP in FCA induced arthritic rats is due to the increase in the liver and bone erosion and periarticular osteopenia, as the enzyme is released in to the circulation in the course of bone formation and resorption (Rehman, Lane, 2001). The decreased levels of these enzymes on leflunomide and amitriptyline treatments emphasize the decreased bone loss and liver- protective role in the $F C A$ induced arthritic rats (Table XII).

TABLE IX-Changes in Body weight, Spleen and Thymus weight

\begin{tabular}{lccc} 
Group & Body weight gain (g) & Spleen weight (g/100 g body weight) & $\begin{array}{c}\text { Thymus weight (g/100 } \\
\text { body weight) }\end{array}$ \\
\hline $\begin{array}{l}\text { Group I } \\
\text { (vehicle.con) }\end{array}$ & $15.2 \pm 1.63$ & $0.251 \pm 0.006$ & $0.079 \pm 0.002$ \\
Group II & & \\
(Arth.con) & $3.1 \pm 1.16$ & $0.54 \pm 0.009$ & $0.115 \pm 0.012$ \\
$\mathrm{a}^{* *}$ & $\mathrm{a}^{* * *}$ & $0.090 \pm 0.004$ \\
Group III & $8.3 \pm 2.45$ & $0.47 \pm 0.02$ & $\mathrm{~b}^{*}$ \\
(LEF) & $\mathrm{a}^{*}$ & $\mathrm{a}^{* * *} \mathrm{~b}^{* *}$ & $0.079 \pm 0.001$ \\
Group IV & $12.2 \pm 0.71$ & $0.29 \pm 0.007$ & $\mathrm{~b}^{* *}$ \\
(LELA) & $\mathrm{b}^{* *}$ & $\mathrm{~b}^{* * *}$ & $0.084 \pm 0.004$ \\
Group V & $8.4 \pm 0.41$ & $0.309 \pm 0.007$ & $\mathrm{~b}^{*}$ \\
(LEHA) & $\mathrm{a}^{*}$ & $\mathrm{a}^{* *} \mathrm{~b}^{* * *}$ & \\
\hline
\end{tabular}

Values are expressed as mean \pm SEM, $n=6$. Comparisons were made between:

a - Group I vs II, III, IV and V.

b - Group II vs III, IV and V

Symbols represent statistical significance:

$* * *_{-} \mathrm{p}<0.001$

$* *-\mathrm{p}<0.01$,

$*-\mathrm{p}<0.05$ 
TABLE X-Effect of leflunomide and amitriptyline on Haematological parameters in FCA induced Arthritic rats

\begin{tabular}{|c|c|c|c|c|c|}
\hline $\begin{array}{l}\text { Hematological } \\
\text { parameters }\end{array}$ & $\begin{array}{c}\text { Group-I } \\
\text { (Vehicle.con) }\end{array}$ & $\begin{array}{l}\text { Group-II } \\
\text { (Arth.con) }\end{array}$ & $\begin{array}{l}\text { Group-III } \\
\text { (LEF) }\end{array}$ & $\begin{array}{l}\text { Group-IV } \\
\text { (LELA) }\end{array}$ & $\begin{array}{c}\text { Group-V } \\
\text { (LEHA) }\end{array}$ \\
\hline $\mathrm{RBC}\left(\mathrm{x} 10^{6} / \mu \mathrm{l}\right)$ & $7.02 \pm 0.09$ & $\begin{array}{c}5.77 \pm 0.07 \\
a^{* * *}\end{array}$ & $\begin{array}{c}6.97 \pm 0.05 \\
\mathrm{~b}^{* * *}\end{array}$ & $\begin{array}{c}7.08 \pm 0.05 \\
\mathrm{~b}^{* * *}\end{array}$ & $\begin{array}{c}7.01 \pm 0.03 \\
b^{* * *}\end{array}$ \\
\hline $\operatorname{WBC}\left(\times 10^{3} / \mu \mathrm{l}\right)$ & $7.35 \pm 0.25$ & $\begin{array}{c}12.80 \pm 0.2 \\
\mathrm{a}^{* * *}\end{array}$ & $\begin{array}{c}10.98 \pm 0.08 \\
a^{* * *} b^{*}\end{array}$ & $\begin{array}{c}8.40 \pm 0.2 \\
b^{* * *}\end{array}$ & $\begin{array}{c}9.25 \pm 0.45 \\
a^{* *} b^{* *}\end{array}$ \\
\hline $\mathrm{Hb}(\mathrm{g} / \mathrm{dL})$ & $12.51 \pm 0.4$ & $\begin{array}{c}10.40 \pm 0.1 \\
a^{* *}\end{array}$ & $\begin{array}{c}10.85 \pm 0.05 \\
\mathrm{a}^{* *}\end{array}$ & $\begin{array}{c}13.34 \pm 0.2 \\
\mathrm{~b}^{* * *}\end{array}$ & $\begin{array}{c}11.82 \pm 0.1 \\
\mathrm{~b}^{* *}\end{array}$ \\
\hline $\operatorname{ESR}\left(\mathrm{mm} / 1^{\mathrm{st}} \mathrm{hr}\right)$ & $3.51 \pm 0.5$ & $\begin{array}{c}11.50 \pm 0.5 \\
a^{* * *}\end{array}$ & $\begin{array}{c}9.50 \pm 0.5 \\
\mathrm{a}^{* *}\end{array}$ & $\begin{array}{c}3.52 \pm 0.5 \\
\mathrm{~b}^{* * *}\end{array}$ & $\begin{array}{c}4.52 \pm 0.5 \\
b^{* *}\end{array}$ \\
\hline PCV (\%) & $54.70 \pm 0.6$ & $\begin{array}{c}34.75 \pm 0.37 \\
a^{* * *}\end{array}$ & $\begin{array}{c}40.57 \pm 0.57 \\
a^{* * *} b^{* *}\end{array}$ & $\begin{array}{c}48.64 \pm 0.49 \\
a^{* *} b^{* * *}\end{array}$ & $\begin{array}{c}42.41 \pm 0.45 \\
a^{* * *} b^{* * *}\end{array}$ \\
\hline 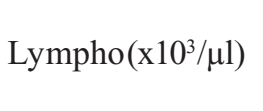 & $6.23 \pm 0.2$ & $\begin{array}{c}16.12 \pm 0.7 \\
\mathrm{a}^{* * *}\end{array}$ & $\begin{array}{c}11.90 \pm 0.7 \\
a^{* *} b^{*}\end{array}$ & $\begin{array}{c}4.90 \pm 0.3 \\
\mathrm{~b}^{* * *}\end{array}$ & $\begin{array}{c}5.95 \pm 0.15 \\
\mathrm{~b}^{* * *}\end{array}$ \\
\hline $\mathrm{MCHC}$ & $36.25 \pm 0.15$ & $\begin{array}{c}32.50 \pm 0.20 \\
\mathrm{a}^{* * *}\end{array}$ & $\begin{array}{c}34.42 \pm 0.1 \\
\mathrm{a}^{* *} \mathrm{~b}^{* *}\end{array}$ & $\begin{array}{c}36.95 \pm 0.15 \\
\mathrm{~b}^{* * *}\end{array}$ & $\begin{array}{c}36.05 \pm 0.25 \\
\mathrm{~b}^{* * *}\end{array}$ \\
\hline
\end{tabular}

Values are expressed as mean \pm SEM, $n=6$. Comparisons were made between:

a - Group I vs II, III, IV and V.

b - Group II vs III, IV and V

Symbols represent statistical significance:

$* * *-\mathrm{p}<0.001$

$* *-\mathrm{p}<0.01$

$*-p<0.05$

TABLE XI- Effect of leflunomide and amitriptyline on RF and CRP in FCA induced arthritic rats

\begin{tabular}{|c|c|c|c|c|}
\hline \multirow{2}{*}{ Group } & \multicolumn{2}{|c|}{ RF (IU/mL) } & \multicolumn{2}{|c|}{ CRP (mg/dL) } \\
\hline & Day 14 & Day 21 & Day 14 & Day 21 \\
\hline Arthritic control & $54.34 \pm 3.76$ & $67.72 \pm 2.03$ & $5.74 \pm 0.05$ & $6.56 \pm 0.25$ \\
\hline LEF & $46.01 \pm 1.73$ & $\begin{array}{c}36.67 \pm 2.03 \\
* *\end{array}$ & $\begin{array}{c}5.1 \pm 0.1 \\
\quad *\end{array}$ & $\begin{array}{c}4.45 \pm 0.25 \\
* *\end{array}$ \\
\hline LELA & $\begin{array}{c}30.32 \pm 2.03 \\
* * *\end{array}$ & $\begin{array}{c}23.33 \pm 1.45 \\
* * *\end{array}$ & $\begin{array}{c}3.12 \pm 0.07 \\
* * *\end{array}$ & $\begin{array}{c}1.70 \pm 0.1 \\
* * *\end{array}$ \\
\hline LEHA & $\begin{array}{c}37.32 \pm 2.33 \\
* *\end{array}$ & $\begin{array}{c}32.67 \pm 1.20 \\
* * *\end{array}$ & $\begin{array}{c}4.54 \pm 0.19 \\
* * *\end{array}$ & $\begin{array}{c}3.25 \pm 0.15 \\
* * *\end{array}$ \\
\hline
\end{tabular}

Values are expressed as mean \pm SEM, $n=6$. Comparisons were made between: Arthritic control vs LEF, LELA and LEHA Symbols represent statistical significance:

\footnotetext{
$* * *-\mathrm{p}<0.001$

$* *-\mathrm{p}<0.01$,

$*-\mathrm{p}<0.05$
} 
TABLE XII- Effect of leflunomide and amitriptyline on Biochemical parameters in FCA induced Arthritic rats

\begin{tabular}{|c|c|c|c|c|c|}
\hline Biochemical parameters & $\begin{array}{c}\text { Group-I } \\
\text { (Vehicle.con) }\end{array}$ & $\begin{array}{c}\text { Group-II } \\
\text { (Arth.con) }\end{array}$ & $\begin{array}{l}\text { Group-III } \\
\text { (LEF) }\end{array}$ & $\begin{array}{l}\text { Group-IV } \\
\text { (LELA) }\end{array}$ & $\begin{array}{l}\text { Group-V } \\
\text { (LEHA) }\end{array}$ \\
\hline $\operatorname{AST}(\mathbf{I U} / \mathbf{L})$ & $44.33 \pm 0.88$ & $\begin{array}{c}92.33 \pm 1.45 \\
a^{* * *}\end{array}$ & $\begin{array}{l}66.67 \pm 1.2 \\
a^{* * *} b^{* * *}\end{array}$ & $\begin{array}{c}51.3 \pm 0.88 \\
a^{*} b^{* * *}\end{array}$ & $\begin{array}{l}67.7 \pm 1.2 \\
a^{* * *} b^{* * *}\end{array}$ \\
\hline ALT (IU/L) & $40.2 \pm 1.53$ & $\begin{array}{c}77.0 \pm 1.73 \\
a^{* * *}\end{array}$ & $\begin{array}{c}56.7 \pm 0.88 \\
a^{* * *} b^{* * *}\end{array}$ & $\begin{array}{c}51.3 \pm 1.45 \\
a^{* *} b^{* * *}\end{array}$ & $\begin{array}{l}57.1 \pm 2.08 \\
a^{* * *} b^{* * *}\end{array}$ \\
\hline $\operatorname{ALP}(I U / L)$ & $237.67 \pm 3.48$ & $\begin{array}{c}351.67 \pm 0.38 \\
\mathrm{a}^{* * *}\end{array}$ & $\begin{array}{c}296.32 \pm 2.52 \\
a^{* * *} b^{* * *}\end{array}$ & $\begin{array}{c}251.01 \pm 1.45 \\
a^{*} b^{* * *}\end{array}$ & $\begin{array}{c}297.67 \pm 1.76 \\
a^{* * *} b^{* * *}\end{array}$ \\
\hline Serum cholesterol (mg/dL) & $111.15 \pm 3.97$ & $\begin{array}{c}171.58 \pm 5.3 \\
\mathrm{a}^{* * *}\end{array}$ & $\begin{array}{c}139.9 \pm 8.3 \\
a^{*} b^{* * *}\end{array}$ & $\begin{array}{c}115.16 \pm 3.1 \\
\mathrm{~b}^{* * *}\end{array}$ & $\begin{array}{c}123.66 \pm 6.8 \\
b^{* * *}\end{array}$ \\
\hline Serum triglyceride $(\mathrm{mg} / \mathrm{dL})$ & $109.21 \pm 5.1$ & $\begin{array}{c}174.12 \pm 4.3 \\
\mathrm{a}^{* * *}\end{array}$ & $\begin{array}{c}151.55 \pm 6.2 \\
a^{* *} b^{*}\end{array}$ & $\begin{array}{c}122.47 \pm 2.9 \\
b^{* * *}\end{array}$ & $\begin{array}{c}138.89 \pm 4.9 \\
a^{*} b^{* * *}\end{array}$ \\
\hline Serum albumin (mg/dL) & $2.90 \pm 0.03$ & $\begin{array}{c}2.19 \pm 0.05 \\
a^{* * *}\end{array}$ & $\begin{array}{c}2.34 \pm 0.05 \\
a^{* * *} b^{*}\end{array}$ & $\begin{array}{c}2.84 \pm 0.05 \\
\mathrm{~b}^{* * *}\end{array}$ & $\begin{array}{c}2.68 \pm 0.03 \\
a^{* *} b^{* * *}\end{array}$ \\
\hline Serum urea $(\mathrm{mg} / \mathrm{dL})$ & $30.33 \pm 2.4$ & $\begin{array}{c}42.67 \pm 1.2 \\
\mathrm{a}^{* * *}\end{array}$ & $\begin{array}{c}33.67 \pm 0.88 \\
\mathrm{~b}^{* * *}\end{array}$ & $\begin{array}{c}27.67 \pm 0.88 \\
\mathrm{~b}^{* * *}\end{array}$ & $\begin{array}{c}31.02 \pm 0.58 \\
\mathrm{~b}^{* * *}\end{array}$ \\
\hline Serum creatinine (mg/dL) & $0.72 \pm 0.02$ & $\begin{array}{c}0.85 \pm 0.01 \\
a^{* *}\end{array}$ & $\begin{array}{c}0.55 \pm 0.03 \\
\mathrm{~b}^{* * *}\end{array}$ & $\begin{array}{c}0.41 \pm 0.01 \\
\mathrm{~b}^{* * *}\end{array}$ & $\begin{array}{c}0.64 \pm 0.02 \\
\mathrm{~b}^{* * *}\end{array}$ \\
\hline
\end{tabular}

Values are expressed as mean \pm SEM, $n=6$. Comparisons were made between:

a - Group I vs II, III, IV and V.

b - Group II vs III, IV and V

Symbols represent statistical significance:

$* * *_{-} \mathrm{p}<0.001$

$* *-\mathrm{p}<0.01$

$*-p<0.05$

The increased cholesterol level in FCA induced arthriticratsmightbeduetothepresenceofinflammatory mediators specifically the proinflammatory cytokines TNF- $\alpha$, IL-1, and IL-6. TNF- $\alpha$ has been found to produce a $25 \%$ increases in serum cholesterol level and 2-3 fold increases in hepatic HMG-COA reductase activity in animals (Memon et al., 1993). Thus the increased level of TNF- $\alpha$ in arthritic rat might also be the cause for the increased level of total cholesterol. Significant increases triglyceride level in arthritic rats might be due to the decreased activity of lipoprotein lipase. Lipoprotein lipase is the main catabolic enzyme for TG rich lipids; it hydrolyzes TG to free fatty acid by acting on circulating chylomicrons and VLDL. In addition, an increased level of TNF- $\alpha$ also increases the TG level by stimulating LDL production (Grunfeld, Feingold, 1992). The present investigation reveals the significant increased level of $\mathrm{TG}$ observed in FCA induced arthritic rats might also increased TNF- $\alpha$ level in these animals. All these lipid metabolic changes are brought back to the normal level by leflunomide alone and combination with amitriptyline treated groups (Table XII). 
In the present study, there was a significant decrease in Albumin level in arthritic rats. The FCA in arthritis causes changes in plasma protein concentrations that are manifested as an increase in the globulin fraction and decrease in the albumin fraction (Cawthrone, Palmer, Green, 1976). General reduction of liver protein synthesis can be assessed by measuring albumin levels because this protein level is lowered during inflammation and also reported that IL-1 reduces the albumin synthesis as well the released mediators such as bradykinin, histamines and PGs. During inflammation, they increase the permeability of vascular tissue to albumin leading to a reduction in its serum level (Lewises, Bishop, Aspinall, 1998). Results in table XII shows the decreased albumin level in arthritic condition was brought back near to normal level in all the treatment groups. In comparison among the treatment groups, leflunomide and amitriptyline combination-treated groups shown more significant $(\mathrm{p}<0.001)$ increases in serum albumin level.

The increased serum urea and creatinine level in an arthritic rat are accompanied by a lowered urine urea, uric acid, and creatinine level; it might be the causes of renal dysfunction (Pedersen et al., 1995). The increased serum urea in arthritic rats was hypothesized that consequential fraction of serum urea in arthritic rats comes from arginine synthesized in the kidney (Filho et al., 2003). Results of this study also show the increased serum urea level and in additional increased serum creatinine level was found in FCA induced arthritic rats, which lead to the kidney dysfunction in arthritic rats. Alterations were normalized greater extent $(p<0.001)$ in all the treatment groups (Table XII).

Radiographic changes in $F C A$ induced rheumatoid arthritic rats are the diagnostic measures which indicate the severity of the disease. Soft tissue swelling around the ankle joint of arthritic rats were considered to be due to edema of periarticular tissues such as ligament and capsule (Selvam et al., 2007). In FCA induced RA rats, bone erosion representing the bony destruction were evident on bone unprotected by cartilage. Since this joint are exposed directly to proinflammatory cytokines such as IL-1 and TNF- $\alpha$ which stimulates the chondrocytes to produce proteolytic enzymes such as collagenase, glycohydrolases and neutral protease and degrade the cartilage which leads to diminished joint space (Sudaroli, Chattterjee, 2007). In this study arthritic control animals showed severe inflammation with diffused joint space and bone erosion. leflunomide and amitriptyline combination-treated groups showed clear joint space with no evidence of bone erosion and inflammation. leflunomide alone treated group showed mild inflammation with diffused joint space (Figure 1).

The monoamine hypothesis of depression suggests that a functional deficit of NA and/or 5-HT at certain sites of the brain (Schildkraut, 1965). In this study 5-HT and NA were found to be a more significant reduction in the adjuvant-induced arthritic animals, which conforms rheumatoid arthritis is associated with depression. leflunomide and amitriptyline combination-treated groups showed a significant increase in NA and 5-HT levels in arthritic animals. leflunomide alone treated group did not show any significant changes. In comparison between LELA and LEHA treated group, LEHA has more significant antidepressant action (Table XIII).

In histopathological study arthritic control showed severe joint cartilage destruction and high inflammatory cellular infiltrations. leflunomide and amitriptyline combination- treated group showed no sign of joint destruction and cellular infiltrations. It confirmed that leflunomide and amitriptyline combination have significant cartilage protective effect (Figure 2). 


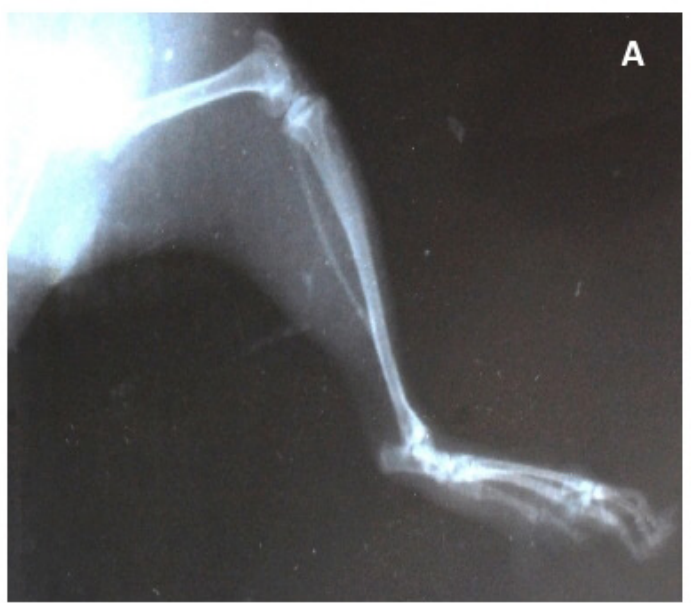

Vehicle control

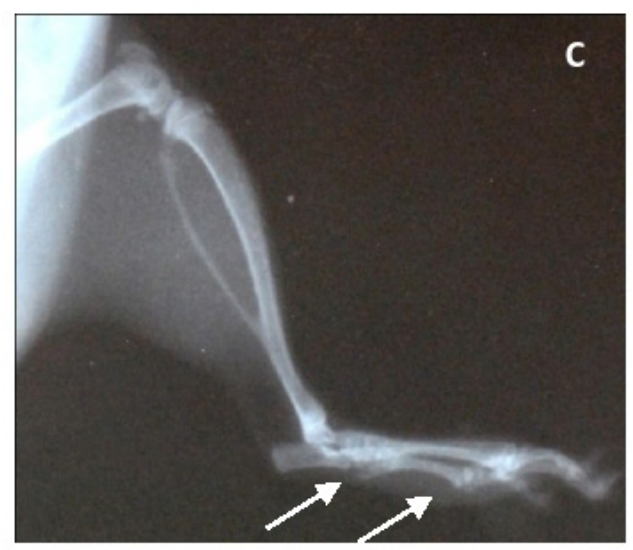

Leflunomide $12 \mathrm{mg} / \mathrm{kg}$

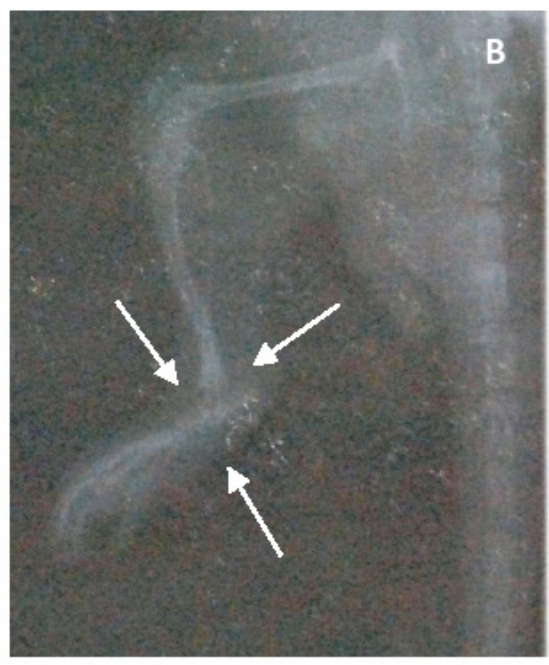

Arthritic control

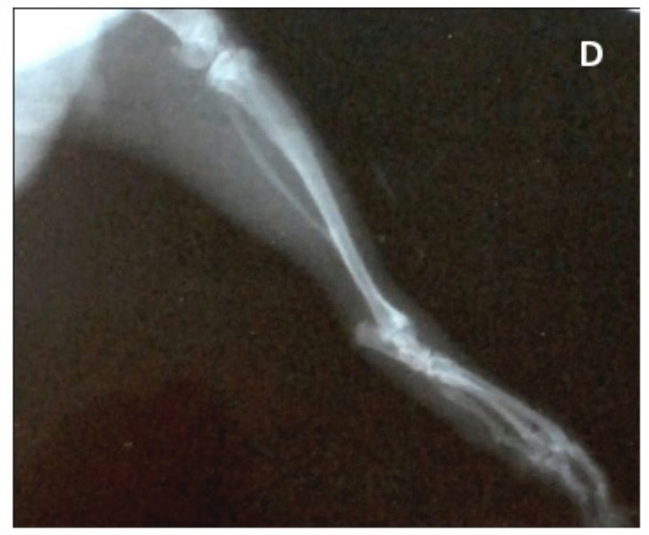

Leflunomide (12 mg/kg) + Low dose Amitriptyline (9mg/kg)

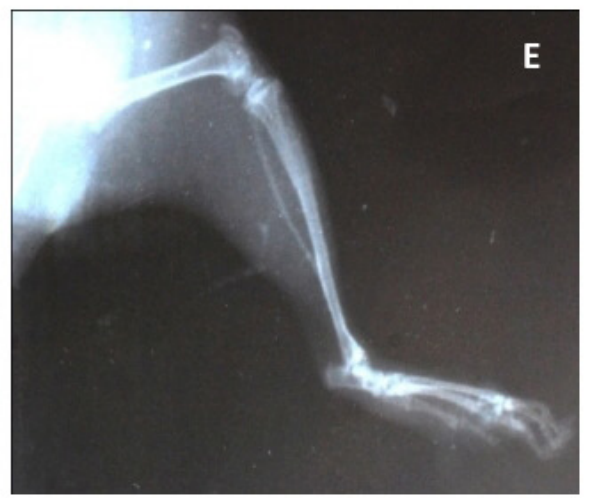

Leflunomide (12 mg/kg) + High dose Amitriptyline (18 mg/kg)

FIGURE 1 - Radiographic analysis of FCA induced arthritis in rats. 
TABLE XIII- Effect of leflunomide and amitriptyline on Brain neurotransmitters in FCA induced arthritic rats

Group I

(vehicle.con)

\section{Group II}

(Arth.con)

Group III

(LEF)

\section{Group IV}

(LELA)

\section{Group V \\ (LEHA)}

$$
4.22 \pm 0.05
$$

$3.12 \pm 0.07$

$\mathrm{a}^{* * *}$

$3.30 \pm 0.07$
$\mathrm{a}^{* * *}$

$3.94 \pm 0.03$

$a^{* *} b^{* * *}$
$4.15 \pm 0.03$
$\mathrm{b}^{* * *}$

$1.89 \pm 0.06$

$0.80 \pm 0.03$

$0.93 \pm 0.04$

$\mathrm{a}^{* * *}$

$1.61 \pm 0.05$

$\mathrm{a}^{* * *} \mathrm{~b}^{* * *}$

$1.73 \pm 0.04$

$\mathrm{b}^{* * *}$

Values are expressed as mean $\pm \mathrm{SEM}, \mathrm{n}=6$. Comparisons were made between:

a - Group I vs II, III, IV and V;

b - Group II vs III, IV and V

Symbols represent statistical significance:

$* * *$ - $\mathrm{p}<0.001$,

$* *-\mathrm{p}<0.01$

$*-\mathrm{p}<0.05$ 


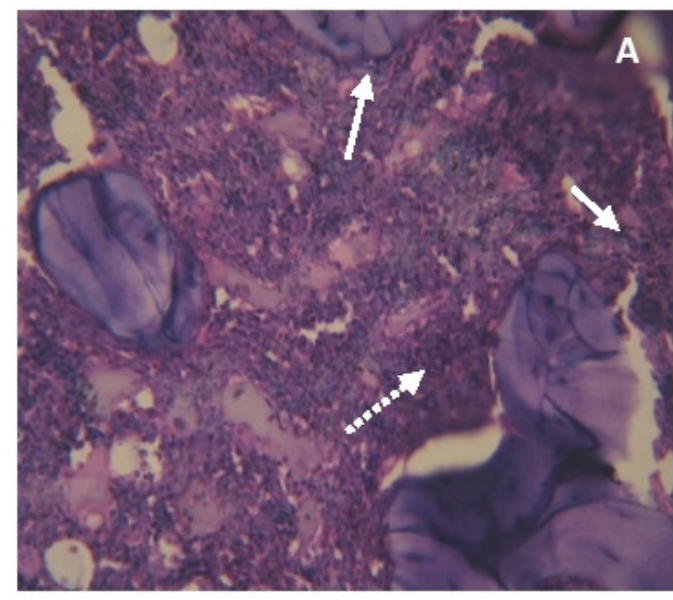

Arthritic control

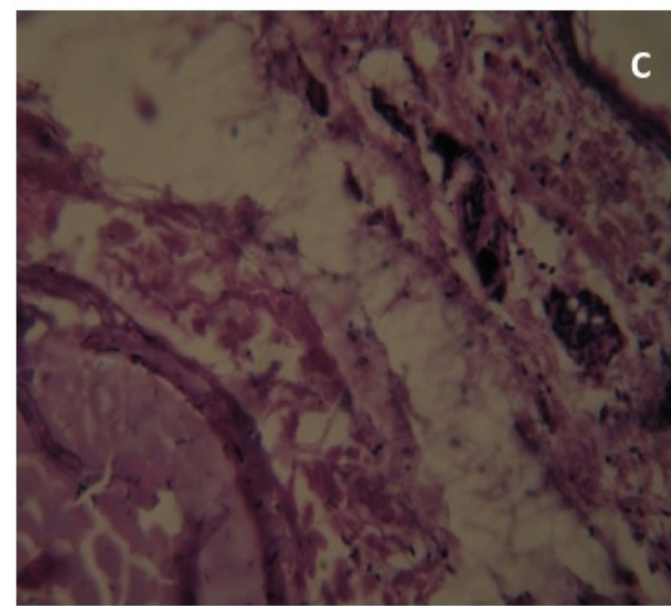

Leflunomide $(12 \mathrm{mg} / \mathrm{kg})+$ A,itriptyline $(9 \mathrm{mg} / \mathrm{kg})$

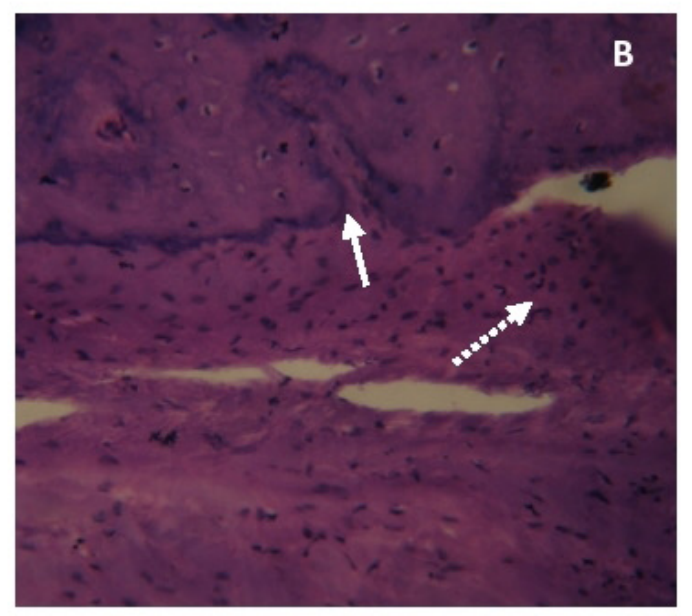

Leflunomide (12 mg/kg)

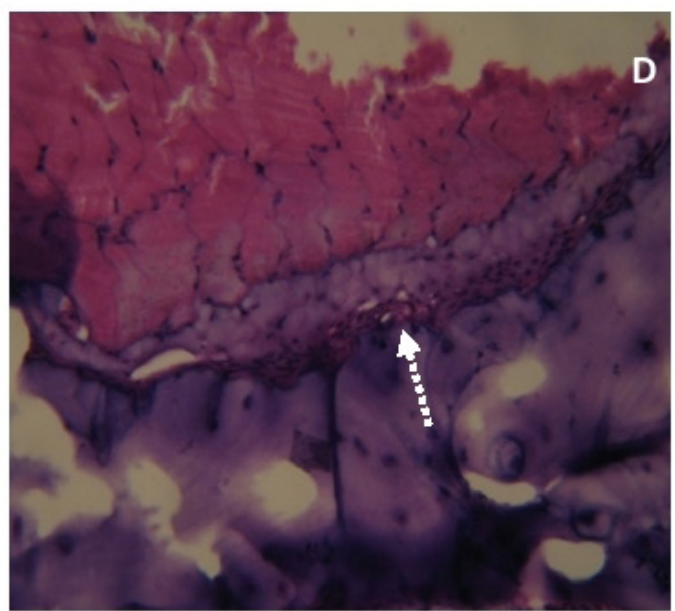

Leflunomide $(12 \mathrm{mg} / \mathrm{kg})+$ A,itriptyline $(18 \mathrm{mg} / \mathrm{kg})$

\section{$\longrightarrow$ Cartilage erosion $\quad ; \quad \cdots+\cdots+$ Inflammatory Cells}

FIGURE 2 - Histopathological changes in joints of FCA induced rats (H \& E, X 100).

\section{CONCLUSION}

The present data indicate that leflunomide and amitriptyline combination has more significant effect on rheumatoid arthritis pain associated depressive condition in FCA induced arthritic rats as compared to leflunomide alone treated group. LELA has more significant and potent action on arthritic condition but LEHA has moderate action. In pain associated depressive condition LEHA showed hyperactivity but LELA produce prominent action.

In the emergent intervention of the above results it might be concluded that leflunomide combination with
Low dose amitriptyline has the profound beneficial effect on pain associated depression in FCA induced rheumatoid arthritis. Further clinical data are required to explore this combination to improve the physical and psychological states of rheumatoid arthritis patients.

\section{REFERENCES}

Agarwal RB, Rangari VD. Phytochemical investigation and evaluation of anti-inflammatory and anti-arthritic activities of essential oil of strobilanthusixiocephala Benth. Indian J Exp Biol. 2003;41(8):890-894. 
Bandila KL, McDuffie FC.Reactivity of rheumatoid factor with autologous IgG antibodies. Arthritis Rheum. 1969;12(2):74-81.

Campbell S, MacQueen G. An update on regional brain volume differences associated with mood disorders. Curr opin Psychiatry. 2006;19(1):25-33.

Cawthorne MA, Palmer ED, Green J. Adjuvant induced arthritis and drug metabolising enzymes. Biochem Pharmacol. 1976;25(24):2683-2688.

Challahan LF, Kaplan MR, Pincus T. The Beck depression inventory, centre for epidemiological studies depression scale (CES-D) and general Well-Being schedule depression subscale in rheumatoid arthritis. Arthritis care Res. 1991;4(1):3-11.

Creed F. Psychological disorders in rheumatoid arthritis: a growing consensus. Ann Rheum Dis. 1990;49(10):808-812.

Curatolo M, Bogduk N. Pharmacologic pain treatment of musculoskeletal disorders: current perspectives and future prospects. Clin J Pain. 2001;17(1):25-32.

Dunhan NW, Miya TS. A note on a simple apparatus for detecting neurological deficit in rats and mice. J Am Pharm Assoc. 1957;46(3):208-209.

Eric GB, Lawrence JL. Rheumatoid arthritis and its therapy. The Text Book of Therapeutics: Drug and Disease Management. Edn 16, Baltimore: Williams and Wilkins Company, 1996, 1156.

Filho PY, Bracht A, Ishii-Iwato EL, Lousano SH, Bracht L, Kelmer-Bracht AM. The urea cycle in the liver of arthritic rats. Mol Cell Biochem. 2003;243(1-2):97-106.

Fishbain D. Evidence-based data on pain relief with antidepressants. Ann Med. 2000;32(5):305-16.

Frank RG, Beck NC, Parker JC, Kashani JH, Elliott TR, Haut AE, et al. Depression in rheumatoid arthritis. J Rheumatol. 1988;15(6):920-925.

Ghai CL. A textbook of practical physiology. Jaypee brothers Medical publishers (P) Ltd, New Delhi, India, 1993.

Gilliland BC. Arthritic and periarthritic disorders. In: Bonica JJ, editor. The management of pain. Malvern, Pennsylvania: Lea \& Febrig, 1990;329-351.

Grunfeld C, Feingold KR. Role of cytokines in inducing hyperlipidemia. Diabetes. 1992;41(Suppl 2):97-101.

Kumar VL, Roy S, Sehal R, Padhy BM. A comparative study on the efficacy of rofecoxib in monoarticular arthritis induced by latex of Calotropis procera and Freund's Complete Adjuvant. Inflammopharmacology. 2006;14(1-2):17-21.

Lewis EJ, Bishop J, Aspinall SJ. A simple inflammation model that distinguishes between the actions of anti-inflammatory and antirheumatic drugs. Inflamm Res. 1998;47(1):26-35.

Maes M, Smith R, Scharpe S. The monocyte-T-lymphocyte hypothesis of major depression. Psychoneuroendocrinology. 1995;20(2):111-116.

Magni G, Moreschi C, Rigatti Luchini S, Merskey H. Prospective study on the relationship between depressive symptoms and chronic musculo-skeletal pain. Pain. 1994;56(3):289-297.

Marcelletti JF, Nakamura RM. Assessment of serological markers associated with rheumatoid arthritis. Diagnostic autoantibodies and conventional disease activity markers. Clin Appl Immunol Rev. 2003;4(2):109-123.

McConkey B, Crockson RA, Crockson AP, Nilkinson AR. The effect of some anti-inflammatory drugs on the acute-phase proteins in rheumatoid arthritis. Q J Med. 1973;32(168):785-91.

Memon RA, Grunfeld C, Moser AH, Feingold KR. Tumor necrosis factor mediates the effect of endotoxin on cholesterol and triglyceride metabolism in mice. Endocrinology. $1993 ; 132(5): 2246-2253$.

Merskey H. Pain terms; a list with definitions and notes on the usage. Recommended by the IASP Sub-Committee on Taxonomy. Pain. 1979;6(3):249-252.

Mizoguchi K, Yuzurihara M, Ishige A, Sasaki H, Tabira T. Chronic stress impairs rotarod performance in rats: implications for depressive state. Pharmacol Biochem Behav. 2002;7(1-2):79-84.

Mowat AG. Anaemia in rheumatoid arthritis. Mod Trends Rheumatol. 1971;2:106-116.

Sllaie R, Tredger JM, Williams R. Drug and liver part 1: testing liver function. Biopharm \& Drug dispos. 1991;12: 251-259.

Koopman WJ, Schrohenloher RE. Rheumatoid factor and human disease. Clin Immunol News. 1990;10(9):137-141.

Pearson CM, Wood FD. Studies of arthritis and other lesions induced in rats by the injection of mycobacterial adjuvant. Pathologic details of the arthritis and spondylitis. Am J Pathol. 1963;42(1):73-95. 
Pedernera AM, Guardia T, Calderon CG, Rotelli AE, Rocha NE, Genaro SD. Anti-ulcerogenic, and anti-inflammatory activity of the methanolic extract of Larrea divaricate Cav. in rat. J Ethanopharmacol. 2006;105(3):415-420.

Pedersen LM, Nordin $H$, Svensson B, Bliddal $H$. Microalbuminuria in patients with rheumatoid arthritis. Ann Rheum Dis. 1995;54(3):189-192.

Perrot S, Javier RM, Marty M, Le Jeunne C, Laroche F. Is there any evidence to support the use of anti-depressants in painful rheumatological conditions? Systematic review of pharmacological and clinical studies. Rheumatology. 2008;47(8):1117-1123.

Porsolt RD, Le Pichon M, Jalfre M, Chatterjee SS. Depression: a new animal model sensitive to antidepressant treatments. Nature. 1977;266:730-732.

Rainsford KD. Adjuvant polyarthritis in rats: is this a satisfactory model for screening anti-arthritic drugs? Agents Actions 1982;12(4):452-458.

Recommendation of the German Society for Clinical Chemistry (GSCC): Standardization of method for the estimation of enzyme activity in Biological fluids. Z Klin Chem Klin Biochem. 1970;8(6):658-660.

Rehman Q, Lane NE. Bone loss: Therapeutic approaches for preventing bone loss in inflammatory arthritis. Arthritis Res. 2001;3(4):221-227.

Rifai N. Handbook of lipoprotein testing. Washington: AACC press, 1997:99-114.

Roubenoff R, Freeman LM, Smith DE, Adad LW, Dinarello CA, Kehayias JJ. Adjuvant arthritis as a model of inflammatory cahexia. Arth Rheum. 1997;40(3):534-553.

Schildkraut JJ. The catecholamine hypothesis of affective disorders: a review of supporting evidence. Am J Psychiatry. 1965;122(5):509-522.
Schlumpf M, Lichtensteiger W, Langemann H, Waster PG, Hefti F. A fluorimetric micromethod for the simultaneous determination of serotonin, Noradrenaline and dopamine in milligram amount of brain tissue. Biochemical Pharmacology. 1974;23(17):2337-2446.

Selvam R, Ganesan K, Narayanan Raju KV, Gangadharan AC, Manohar BM, Puvanakrishnan R. Low frequency and low intensity pulsed electromagnetic field exerts calcium ATPase activity. Life Sci. 2007;80(26):2403-2410.

Sudaroli M, Chatterjee TK. Evaluation of red and white seed extracts of Abrusprecatorius Linn. Against freund's complete adjuvant induced arthritis in rats. J Med Plants Res. 2007;1(4):086-094.

Sullivan MD, Robinson JP. Antidepressant and anticonvulsant medication for chronic pain. Phys Med Rehabil Clin N Am. 2006;17(2):381-400.

Walz DT, Dimartino MJ, Misher A. Adjuvant induced arthritis in rats II. Drug effects on physiologic, biochemical and immunologic parameters. J Pharmacol Exp Ther. 1971;178(1):223-231.

William JK. Arthritis and allied condition - a textbook of rheumatology. Edn 13, Vol.1, A Waverly Company, Baltimore, Tokyo, 1996,133-198.

Yaron I, Shirazi I, Judovich R, Levartovsky D, Caspi D, Yaron M. Fluoxetin and Amitriptyline inhibit Nitric oxide, Prostaglandin $\mathrm{E}_{2}$, and Hyaluronic acid production in human synovial cells and synovial tissue cultures. Arthritis and Rheumatism. 1999;42(12):2561-2568.

Yong DS. Effect of drugs on clinical laboratory test, $4^{\text {th }}$ Eds. AACC Press, 1995.

Yu YC, Koo ST, Kim CH, Lyu Y, Grady JJ, Chung JM. Two variables that can be used as pain indices in experimental animal models of arthritis. J Neurosci Methods. 2002;115(1):107-103.

Received for publication on $20^{\text {th }}$ February 2018 Accepted for publication on $01^{\text {st }}$ February 2019 